\title{
In situ hybridization to detect and identify Burkholderia pseudomallei in human melioidosis
}

\author{
Lin Chuan $\mathrm{Eu}^{1}$, Kien Chai Ong ${ }^{2}$, Jessie Hiu ${ }^{3}$, Jamunarani Vadivelu ${ }^{4}$, Sheila Nathan ${ }^{5}$ and \\ Kum Thong Wong ${ }^{1}$ \\ ${ }^{1}$ Department of Pathology, Faculty of Medicine, University of Malaya, Kuala Lumpur, Malaysia; \\ ${ }^{2}$ Department of Biomedical Science, Faculty of Medicine, University of Malaya, Kuala Lumpur, \\ Malaysia; ${ }^{3}$ Forensic Department, Queen Elizabeth Hospital, Sabah, Malaysia; ${ }^{4}$ Department of Medical \\ Microbiology, Faculty of Medicine, University of Malaya, Kuala Lumpur, Malaysia and ${ }^{5}$ School of \\ Biosciences and Biotechnology, Faculty of Science and Technology, Universiti Kebangsaan Malaysia, \\ Bangi, Selangor, Malaysia
}

\begin{abstract}
Burkholderia pseudomallei causes a potentially fatal infection called melioidosis. We have developed a nonfluorescent, colorimetric in situ hybridization assay using a specific probe to target 16s rRNA of $B$. pseudomallei in formalin-fixed, paraffin-embedded infected tissues for diagnostic purposes and to study infectious disease pathology. A 63-base pair DNA probe was synthesized and labeled with digoxigenin by PCR. Probe specificity was confirmed by BLAST analysis and by testing on appropriate microbial controls. The in situ hybridization assay was specifically and consistently positive for B. pseudomallei, showing strongly and crisply stained, single bacillus and bacilli clusters in mainly inflamed tissues in seven human acute melioidosis cases and experimentally infected mouse tissues. Intravascular and extravascular bacilli were detected in both intracellular and extracellular locations in various human organs, including lung, spleen, kidney, liver, bone marrow, and aortic mycotic aneurysm, particularly in the inflamed areas. Intravascular, intracellular bacteria in melioidosis have not been previously reported. Although the identity of infected intravascular leukocytes has to be confirmed, extravascular, intracellular bacilli appear to be found mainly within macrophages and neutrophils. Rarely, large intravascular, extracellular bacillary clusters/emboli could be detected in both human and mouse tissues. B. cepacia and non-Burkholderia pathogens (16 microbial species) all tested negative. Nonpathogenic $B$. thailandensis showed some cross-hybridization but signals were less intense. This in situ hybridization assay could be usefully adapted for $B$. pseudomallei identification in other clinical specimens such as pus and sputum. Modern Pathology (2014) 27, 657-664; doi:10.1038/modpathol.2013.184; published online 1 November 2013
\end{abstract}

Keywords: Burkholderia pseudomallei; DNA probe; in situ hybridization; melioidosis; 16s rRNA

Burkholderia pseudomallei is a motile, Gram-negative, non-spore-forming soil bacterium that is readily recovered from water and wet soils in endemic areas of Southeast Asia and Northern Australia. ${ }^{1}$ It causes melioidosis, an infectious disease of major public health importance. $B$. pseudomallei is responsible for $20 \%$ of community-acquired septicemia and $40 \%$ of sepsis-related deaths in Northern

Correspondence: Dr Professor KT Wong, MBBS, MPath, FRCPath, MD, Department of Pathology, Faculty of Medicine, University of Malaya, Kuala Lumpur, Wilayah Persekutuan 50603, Malaysia. E-mail: wongkt@ummc.edu.my

Received 11 March 2013; revised 28 August 2013; accepted 29 August 2013; published online 1 November 2013
Thailand, ${ }^{2}$ whereas in northern Australia, it accounts for $6 \%$ of all bacteremias and $32 \%$ of community-acquired bacteremic pneumonia. ${ }^{3}$ In Malaysia, hundreds of cases have been reported in the past decade. ${ }^{4}$ B. pseudomallei has demonstrated high antibiotic resistance ${ }^{5}$ and has been classified as a category B potential bioterrorism agent by the United States Centers for Disease Control and Prevention.

It is believed that melioidosis is greatly underdiagnosed, and the true incidence and epidemiology of the disease in endemic areas remains unknown. ${ }^{4}$ This is partly because melioidosis, often described as a great mimicker, has protean clinical manifestations, including aortic aneurysm. ${ }^{6,7}$ Needless to 
say in infectious diseases, identification of the causative agent and its timeliness is of paramount importance in determining treatment outcome and prognosis. Traditional laboratory diagnosis of melioidosis using the gold standard bacterial culture requires prolonged incubation and laborious biochemical methods such as the API 20NE for confirmation. Molecular techniques using conventional, multiplex, or real-time $\mathrm{PCR}^{8-10}$ and DNA microarrays ${ }^{11}$ have greatly improved the speed of diagnosis. However, these newer methods may suffer from easy contamination leading to false positive results.

The in situ hybridization technique, a molecular assay that uses labeled probes to hybridize with nucleotide targets, can be readily adapted for the detection and identification of microorganisms. We believe the ability to visualize bacilli with this technique could reduce the likelihood of false positive results inherent in other molecular assays. In situ hybridization has been successfully applied to detect various bacteria, including Helicobacter pylori, ${ }^{12}$ Haemophilus influenza, ${ }^{13}$ and Klebsiella pneumoniae. ${ }^{14}$ Recently, Hagen et al ${ }^{15}$ reported a fluorescence in situ hybridization technique using a set of oligonucleotide probes for the identification of B. pseudomallei, B. mallei, and B. thailandensis in bacterial cell smears and experimentally infected mouse tissues. Although the oligonucleotide probes were not specific to $B$. pseudomallei, they were able to differentiate $B$. pseudomallei, $B$. mallei, and $B$. thailandensis using a multiple-probe exclusion approach.

We have developed a larger DNA probe that targets the 16s rRNA of $B$. pseudomallei for its identification in an in situ hybridization assay that uses a nonfluorescent, colorimetric detection method. The purpose is to improve the diagnosis of melioidosis and to develop a research tool to study the pathology and pathogenesis in infected tissues from human cases as well as animal models. As the clinical diagnosis of melioidosis is often not suspected initially, optimal fresh specimens for bacterial culture and molecular investigations are often not sent at the time of biopsy for histopathological examination. As the in situ hybridization technique can be done on standard formalin-fixed, paraffin-embedded tissues, it can be readily adapted for routine pathological diagnosis. In contrast to fluorescence in situ hybridization, a nonfluorescent, colorimetric in situ hybridization has the advantage of facilitating light microscopic assessment of the surrounding tissues in which the bacilli are found without the problems of poor background details and autofluorescence as previously reported. ${ }^{15}$ Herein, we report the demonstration of whole bacilli in infected human and mouse tissues using this technique that is potentially useful for diagnosis and to further understand the spread and pathogenesis of B. pseudomallei in the host.

\section{Materials and methods}

\section{Preparation of Probe Targeting 16s rRNA}

The rRNA sequences of $B$. pseudomallei (strain K96243, reference number: S000406475) and various other bacteria were downloaded from the RNA database project website (http://rdp.cme.msu.edu/). By aligning and comparing these sequences, we identified a 63-nucleotide region between nucleotides 955 and 1017 that appeared to be sufficiently specific and unique for $B$. pseudomallei for probe hybridization. This region had $<50 \%$ sequence similarity to non-Burkholderia bacteria but shared $88.9 \%$ and $90.5 \%$ similarity to B. cepacia and B. thailandensis, respectively.

A forward primer 5'-ACCCTTGACATGGTCGG AAG- $3^{\prime}$ and a reverse primer 5'-CTGTGCGCCG GTTCTCTT-3' that flank this region were designed and synthesized for PCR use. These primers were checked by a BLAST analysis to confirm their specificity. A digoxigenin-labeled DNA probe (Patent pending: PI 2012700008) was made from the reverse-transcriptase PCR (RT-PCR) product of this region. Briefly, RNA was extracted from a pure colony of $B$. pseudomallei using TRIzol reagent (InvitroGen, USA). The RT-PCR was performed using the AMV RT-PCR kit (Promega, USA) with the reverse primer and RNA template to obtain cDNA. The PCR step uses the cDNA template and the HotStarTaq DNA Polymerase kit (QIAGEN, USA) performed in the Veriti 96 Wells Thermal Cycler (Applied Biosystems, USA) using a protocol of $95^{\circ} \mathrm{C}$ for $10 \mathrm{~min}, 35$ cycles at $94^{\circ} \mathrm{C}$ for $1 \mathrm{~min}, 56^{\circ} \mathrm{C}$ for $45 \mathrm{~s}$, $72{ }^{\circ} \mathrm{C}$ for $45 \mathrm{~s}$, and finally $72{ }^{\circ} \mathrm{C}$ for $10 \mathrm{~min}$. The products were purified using the QIAGEN Gel Purification kit (QIAGEN), sequence-confirmed (FirstBase, Malaysia) and cloned using the pGEMT Easy Vector system (Promega, USA). Finally, a second PCR that incorporates digoxigenin-11-dUTP (Roche, Germany) ${ }^{16}$ was done using the cloned RTPCR products as template and the same PCR protocol to produce the probe.

\section{In Situ Hybridization Protocol}

The in situ hybridization was performed as described by Ong et $a l^{17}$ with some modifications. Briefly, bacterial smears and deparaffinized, rehydrated $3 \mu \mathrm{m}$ tissue sections were pretreated sequentially with $0.2 \mathrm{~N} \mathrm{HCl}(20 \mathrm{~min}$, room temperature), Proteinase-K (100 $\left.\mu \mathrm{g}, 20 \mathrm{~min}, 37^{\circ} \mathrm{C}\right)$, and lysozyme ( $1 \mathrm{mg} / \mathrm{ml}, 30 \mathrm{~min}$, room temperature). The sections were then incubated overnight at $42{ }^{\circ} \mathrm{C}$ in standard hybridization buffer together with $\sim 1 \mathrm{ng} / \mathrm{ml}$ of probes. After the washing and blocking steps, anti-digoxigenin antibody (Roche) conjugated with alkaline phosphatase was added followed by the Liquid Permanent Red (Dako, USA) as substrate. The tissues were counterstained with Mayer's hematoxylin and mounted with Faramount 
Table 1 Results of in situ hybridization specificity testing performed on control microorganisms

\begin{tabular}{|c|c|c|}
\hline \multirow[b]{2}{*}{ Microorganisms } & \multicolumn{2}{|c|}{ Results } \\
\hline & $\begin{array}{l}\text { Microorganism cell } \\
\text { smears on glass slides }\end{array}$ & $\begin{array}{l}\text { Formalin-fixed } \\
\text { paraffinized } \\
\text { microorganisms }\end{array}$ \\
\hline \multicolumn{3}{|l|}{ Gram-positive bacteria } \\
\hline Lactobacillus sp. & - & ND \\
\hline $\begin{array}{l}\text { Streptococcus } \\
\text { aureus }\end{array}$ & - & - \\
\hline \multicolumn{3}{|c|}{ Gram-negative bacteria } \\
\hline $\begin{array}{l}\text { Burkholderia } \\
\text { pseudomallei } \\
\text { (2 strains) }\end{array}$ & + & + \\
\hline $\begin{array}{l}\text { Burkholderia } \\
\text { thailandensis }\end{array}$ & + & + \\
\hline $\begin{array}{l}\text { Burkholderia } \\
\text { cepacia }\end{array}$ & - & ND \\
\hline $\begin{array}{l}\text { Aeromonas } \\
\text { hydraphila }\end{array}$ & - & - \\
\hline $\begin{array}{l}\text { Acinetobacter } \\
\text { calcoaciniticus }\end{array}$ & - & - \\
\hline Escherichia coli & - & - \\
\hline $\begin{array}{l}\text { Klebsiella } \\
\text { pneumoniae }\end{array}$ & - & - \\
\hline $\begin{array}{l}\text { Neisseria } \\
\text { gonorrhoeae }\end{array}$ & - & ND \\
\hline $\begin{array}{l}\text { Pseudomonas } \\
\text { aeruginosa }\end{array}$ & - & ND \\
\hline Proteus sp. & - & - \\
\hline $\begin{array}{l}\text { Salmonella } \\
\text { enteriditis }\end{array}$ & - & - \\
\hline $\begin{array}{l}\text { Salmonella } \\
\text { paratyphi }\end{array}$ & - & - \\
\hline Shigella sonnei & - & - \\
\hline $\begin{array}{l}\text { Actinomyces } \\
\text { spp. }^{\mathrm{a}}\end{array}$ & ND & - \\
\hline $\begin{array}{l}\text { Helicobacter } \\
\text { pylori }^{\mathrm{a}}\end{array}$ & ND & - \\
\hline $\begin{array}{l}\text { Mycobacterium } \\
\text { tuberculosis }\end{array}$ & ND & - \\
\hline \multicolumn{3}{|l|}{ Fungus } \\
\hline Candida albicans & - & ND \\
\hline
\end{tabular}

Abbreviations: ND, not done; +, positive; - , negative.

${ }^{a}$ Actinomyces spp, $H$. pylori, and $M$. tuberculosis were human surgical biopsies in which these infections were confirmed.

(Dako) and systematically viewed under a light microscope.

\section{In Situ Hybridization Controls}

Three Burkholderia species, B. pseudomallei (two strains: K96243 and CMS), B. cepacia, and $B$. thailandensis, and 16 non-Burkholderia microorganisms were used as controls to test the specificity of the probe (Table 1). B. mallei was not included in the controls as the isolate was not available. All the microorganisms were grown overnight in LB broth, washed, formalin fixed, and resuspended in phosphate-buffered saline (PBS) before spreading onto silane-coated glass slides as bacteria cell smears. The smears were heat-fixed for $5 \mathrm{~min}$ before use. To prepare formalin-fixed, paraffin-embedded sections of the same bacteria cells, fresh, normal mouse liver and lung tissues were first incubated together with the bacteria in LB broth for $2.5 \mathrm{~h}$, and then washed, formalin fixed, and routinely processed into paraffin blocks. The mouse tissues provided scaffolds for bacteria adhesion and penetration to minimize bacterial cell loss during tissue processing. Formalin-fixed, paraffin-embedded human tissues known to be infected by Mycobacterium tuberculosis, Actinomyces spp., and Helicobacter pylori were also used as additional negative controls.

\section{Human Melioidosis Cases}

A total of seven human autopsy cases of acute melioidosis were studied (Table 2). Four were collected from 1978 to 1996 and archived in the Department of Pathology, Faculty of Medicine, University of Malaya. Three cases were referred from Hospital Queen Elizabeth, Sabah, Malaysia, for diagnostic purposes. Ethical clearance was obtained from the Ethics Committee of the University of Malaya Medical Center. All available tissue samples were tested and all cases (Table 2) were culture proven as melioidosis. Tissue sections ( $3 \mu \mathrm{m}$ thick) from all available paraffin blocks were stained with hematoxylin and eosin and Brown-Hopps Gram stains as previously described, ${ }^{18}$ and examined under a light microscope.

\section{Experimentally Infected Mouse Tissues}

Healthy Balb/c mice $(n=15)$ (obtained from Monash University Sunway Campus, Malaysia) were infected with $\sim 10^{7} \mathrm{CFU} / \mathrm{ml}$ of $B$. pseudomallei via the intraperitoneal (IP) route. Mock-infected mice $(n=3)$ were injected with PBS buffer. The mice were kept in an individual ventilated cage system (ITS, Italy) and observed daily. Tissues from dead mice were harvested, formalin fixed, and routinely processed to prepare paraffin blocks including 15 blocks each of spleen, lung, and liver, and 3 blocks each of stomach and kidney. All the tissues were cut into $3 \mu \mathrm{m}$ thick sections and placed onto silanecoated glass slides for in situ hybridization. All the work involving bacteria and infected animals was done inside a Level II biosafety cabinet, and in accordance with the ethics code set by the Animal House, University of Malaya.

\section{Results}

\section{Probe Specificity}

The probe specificity test results on $B$. pseudomallei, B. cepacia, and B. thailandensis and 16 nonBurkholderia microorganisms are shown in Table 1. B. pseudomallei and B. thailandensis were both in situ hybridization positive in control bacterial smears and formalin-fixed, paraffin-embedded 
Table 2 Clinical features and in situ hybridization results in seven autopsy cases of acute melioidosis

\begin{tabular}{|c|c|c|c|c|c|}
\hline $\begin{array}{l}\text { Case } \\
\text { no. }\end{array}$ & $\begin{array}{l}\text { Sex/age } \\
\text { (years) }\end{array}$ & Clinical features and diagnosis & $\begin{array}{l}\text { Positive culture } \\
\text { obtained from }\end{array}$ & Histopathological features & In situ hybridization results \\
\hline 1 & $\mathrm{M} / 68$ & $\begin{array}{l}\text { Had epididymo-orchitis, pus } \\
\text { surgically drained. Died of } \\
\text { septicemia despite antibiotics. }\end{array}$ & Blood, pus & $\begin{array}{l}\text { Necrotizing inflammation in } \\
\text { the lung with macrophages, } \\
\text { neutrophils, and } \\
\text { lymphocytes. }\end{array}$ & $\begin{array}{l}\text { Some small clusters and } \\
\text { individual bacilli in the lung. }\end{array}$ \\
\hline 2 & $\mathrm{~F} / 18$ & $\begin{array}{l}\text { Had fever, joint pains, severe } \\
\text { headache, and night sweats for } 2 \\
\text { weeks. Developed watery diarrhea } \\
\text { and epigastric pain and started on } \\
\text { crystalline penicillin after admission. } \\
\text { Died of septicemia. }\end{array}$ & Blood & $\begin{array}{l}\text { Necrotizing inflammation } \\
\text { with macrophage dominance } \\
\text { and neutrophils and } \\
\text { numerous 'giant cells' in liver } \\
\text { and lung. }\end{array}$ & $\begin{array}{l}\text { A few bacilli in liver and } \\
\text { lung. }\end{array}$ \\
\hline 3 & $\mathrm{M} / 36$ & $\begin{array}{l}\text { Chest wall abscess } 4 \text { weeks before } \\
\text { admission, treated but did not heal. } \\
\text { Relapsing fever with chills, } \\
\text { drowsiness, tachycardia, tachypnea, } \\
\text { generalized lung rhonchi, and } \\
\text { crepitations and hepatomegaly on } \\
\text { admission. Died of acute fulminant } \\
\text { melioidosis. }\end{array}$ & $\begin{array}{l}\text { Blood, pus (lung, } \\
\text { spleen, kidney and } \\
\text { chest wall) }\end{array}$ & $\begin{array}{l}\text { Necrotizing inflammation } \\
\text { comprising mainly } \\
\text { macrophages and neutrophils } \\
\text { in lung, liver, and kidney, } \\
\text { with some 'giant cells'. }\end{array}$ & $\begin{array}{l}\text { Numerous intra- and } \\
\text { extracellular bacilli in the } \\
\text { lung. Some bacilli also } \\
\text { detected in liver and kidney. }\end{array}$ \\
\hline 4 & $\mathrm{~F} / 19$ & $\begin{array}{l}\text { Known case of diabetes mellitus, } \\
\text { presented with fever, chills, and knee } \\
\text { joint pain. Died of septicemia and } \\
\text { respiratory failure. }\end{array}$ & Blood, Pus (lung) & $\begin{array}{l}\text { Large areas of necrotizing } \\
\text { inflammation in lung, } \\
\text { comprising mainly } \\
\text { macrophages and } \\
\text { neutrophils, with pulmonary } \\
\text { edema and hyaline } \\
\text { membranes in some focal } \\
\text { areas. }\end{array}$ & $\begin{array}{l}\text { A few small clusters and } \\
\text { individual bacilli in lung. }\end{array}$ \\
\hline 5 & $\mathrm{M} / 33$ & $\begin{array}{l}\text { Had pneumonia for a month then } \\
\text { developed multiorgan failure. }\end{array}$ & $\begin{array}{l}\text { Lung and splenic } \\
\text { swabs }\end{array}$ & $\begin{array}{l}\text { Mild inflammation in the } \\
\text { lung, spleen, bone marrow, } \\
\text { and kidney with some } \\
\text { macrophages and neutrophils } \\
\text { observed. Multiple small foci } \\
\text { of necrotizing inflammation } \\
\text { with neutrophils and } \\
\text { macrophages in liver. }\end{array}$ & $\begin{array}{l}\text { Individual and diffuse } \\
\text { clusters of bacilli in lung, } \\
\text { liver, spleen, bone marrow, } \\
\text { and kidney. }\end{array}$ \\
\hline 6 & $\mathrm{M} / 49$ & $\begin{array}{l}\text { Known case of diabetes mellitus. } \\
\text { Admitted for pneumonia, then } \\
\text { discharged but did not improve. } \\
\text { Readmitted in critical condition, } \\
\text { died soon after. }\end{array}$ & Blood, lung swab & Severe lobar pneumonia. & $\begin{array}{l}\text { Small clusters and individual } \\
\text { bacilli in lung. }\end{array}$ \\
\hline 7 & $\mathrm{M} / 58$ & $\begin{array}{l}\text { Known case of diabetes mellitus. Had } \\
\text { low backache for } 2 \text { weeks and } \\
\text { admitted for right adrenal and } \\
\text { paraaortic mass. Treated with } \\
\text { intravenous Ceftazidime. Died from } \\
\text { gastrointestinal bleeding. }\end{array}$ & Blood & $\begin{array}{l}\text { Large necrotic abdominal } \\
\text { aorta aneurysm with } \\
\text { thrombus and necrotic aortic } \\
\text { wall. }\end{array}$ & $\begin{array}{l}\text { Individual and small clusters } \\
\text { of bacilli in mycotic } \\
\text { aneurysm of abdominal aorta. }\end{array}$ \\
\hline
\end{tabular}

${ }^{\mathrm{a} C a s e s} 1-3$ were previously described by Wong et al. ${ }^{19}$

sections, but the signal intensities for B. pseudomallei were relatively stronger compared with $B$. thailandensis. B. pseudomallei was crisply and strongly stained red as single whole bacillus or bacilli clusters (Figure 1a). All other microorganisms, including $B$. cepacia, gave negative results (Figure 1b). The areas of in situ hybridization positivity generally corresponded very well with the areas in which Gram-negative bacilli were stained by the Brown-Hopps method.

\section{In Situ Hybridization on Infected Human Tissues}

Tissues from at least one organ tested positive in all the seven human cases studied and positive staining results were mainly associated with inflammatory lesions (Table 2). The lung was the most likely organ to be positive (cases 1-6). Bacilli were demonstrated in alveolar walls either within capillaries or intracellularly (Figure 2b). In more severe lung parenchymal inflammatory lesions, individual or clusters/chains of bacilli were often numerous (Figure 2a). Within blood vessels in the lungs and other organs, individual 'free-floating' bacillus or intracellular bacilli were observed (Figure 2d). Rarely, large 'free-floating' bacillary clusters or emboli measuring nearly $20 \mu \mathrm{m}$ in diameter could be found (Figure 2c). Bacilli could be detected in kidney glomeruli, possibly within capillaries (Figure 2e), in bone marrow (Figure 2f), and in the wall of the aortic mycotic aneurysm (Table 2, case 7). Intracellular bacteria were found in cells that morphologically resemble macrophages and neutrophils.

\section{In Situ Hybridization on Infected Mouse Tissues}

Overall, bacteria found in tissues from mice with acute melioidosis (all mice died within 3 days after infection) showed very crisp and strong positivity. 

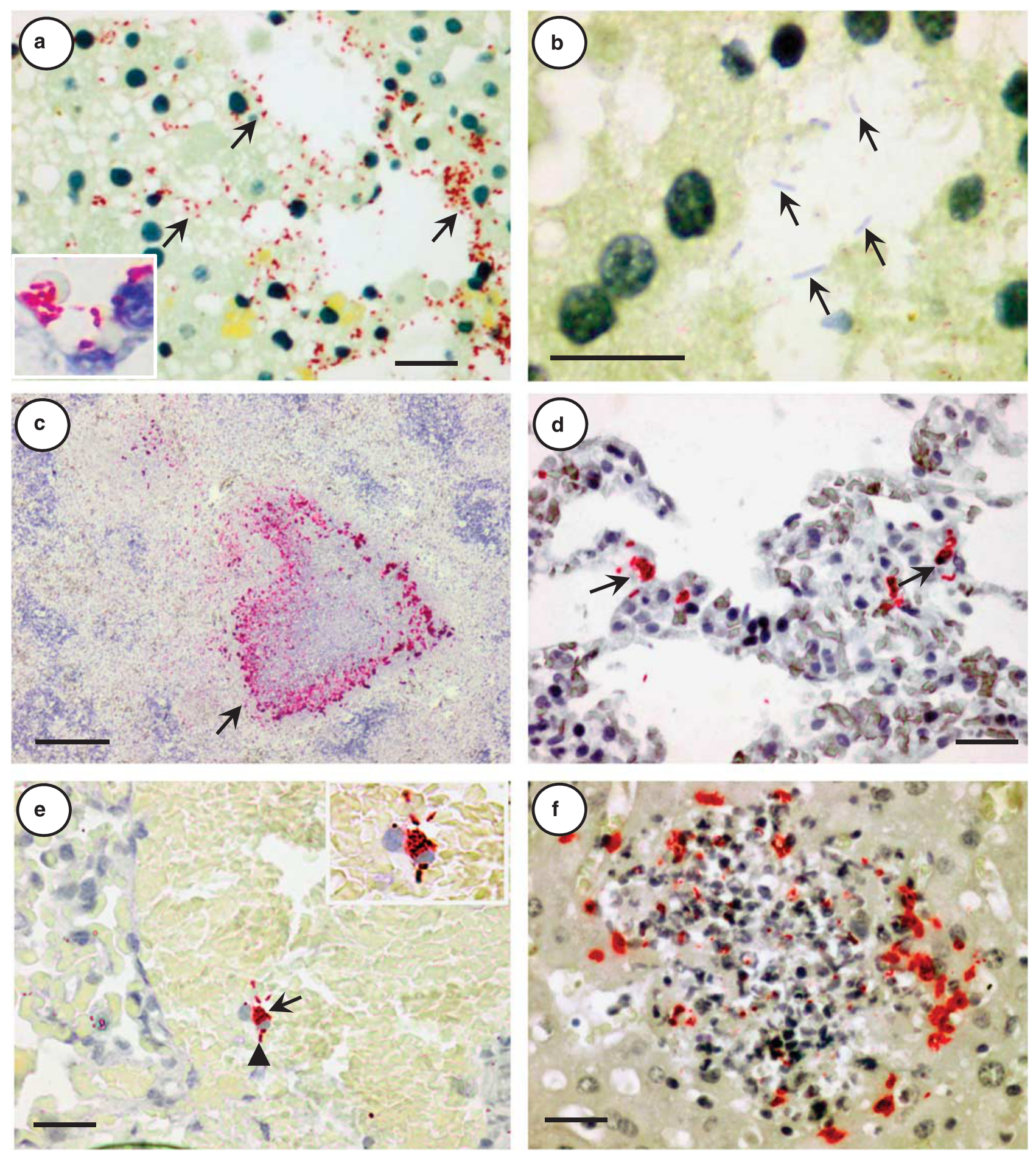

Figure 1 In situ hybridization to detect Burkholderia pseudomallei in control and infected mouse tissues with positive staining shown in red. (a) Formalin-fixed, paraffin-embedded B. pseudomallei bacilli in liver tissue scaffold positively stained as crisp single whole bacillus or bacilli clusters (arrows). The inset shows bacilli in higher magnification. (b) No cross-hybridization was observed in similar tissues containing Acinetobacter spp. bacilli as a negative control (arrows). (c) Numerous positively stained bacteria surrounding a large area of necrosis and inflammation in infected murine spleen (arrow). (d) Single bacillus and small bacilli clusters (arrows) in the alveolar wall of the murine lung. (e) Intracellular (arrow) and extracellular bacilli (arrowhead) found within a blood vessel in the murine lung. Inset shows a higher magnification. (f) Clusters of bacilli around a small abscess in the murine liver. Liquid Permanent Red substrate with Mayer hematoxylin counterstain. Magnification: (a, d, e, and f): $\times 40$ objective; (c): $\times 10$ objective; (b and inset): $\times 100$ objective. Scale bars $=20 \mu \mathrm{m}(\mathbf{a}, \mathbf{b}$, and $\mathbf{d}-\mathbf{f}) ; 100 \mu \mathrm{m}(\mathbf{c})$.

Infection was most severe in the spleen (Figure 1c) and liver (Figure 1f) where large clusters of bacilli with or without surrounding inflammation were observed. Individual intracellular or extracellular bacilli were also well demonstrated. Compared with the spleen and liver, bacilli in the lungs were sparse, 

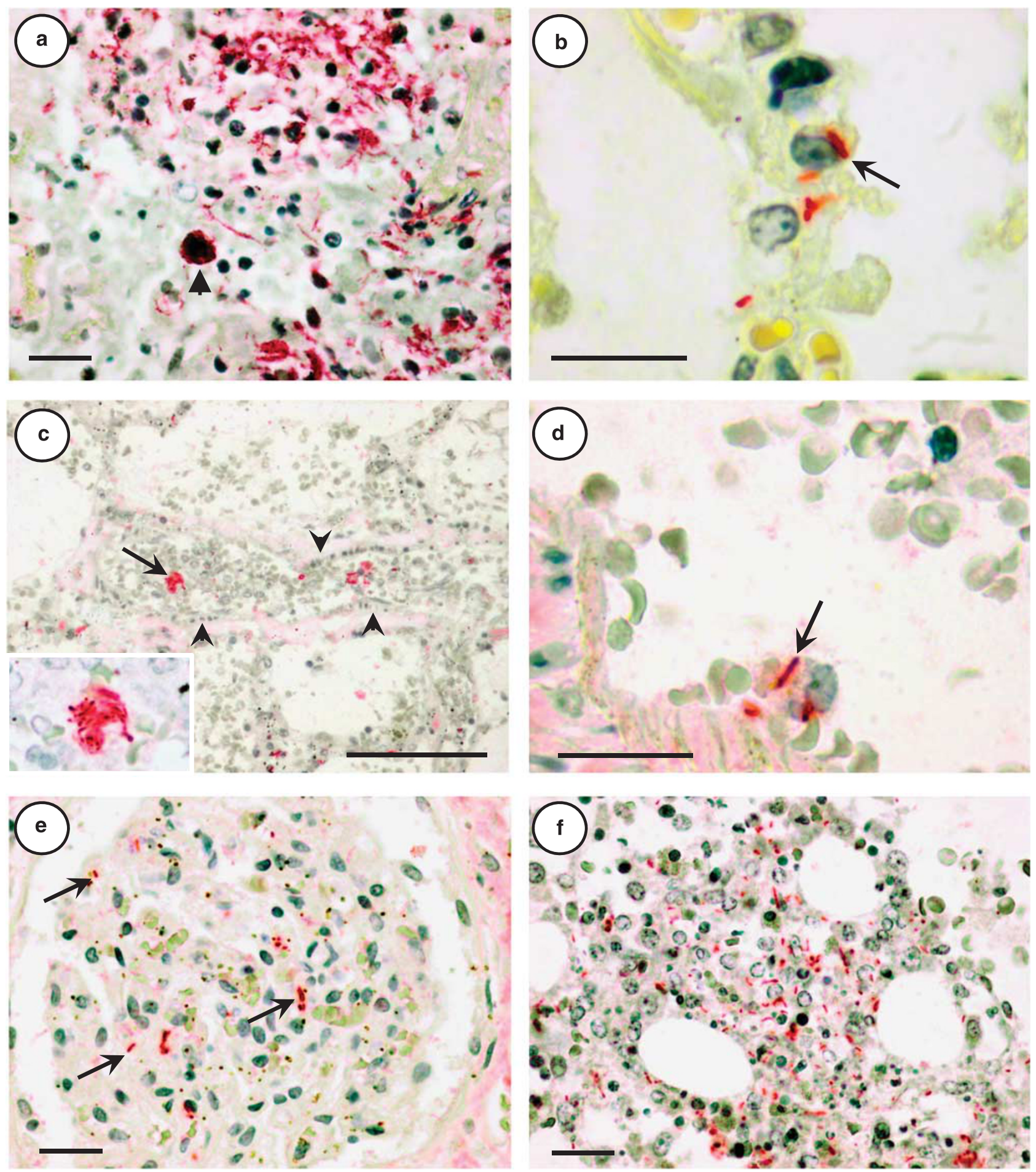

Figure 2 In situ hybridization to detect Burkholderia pseudomallei in human melioidosis cases with positive staining shown in red. (a) In the lung, extracellular and intracellular (arrowhead) bacilli were observed in and around inflammatory parenchymal lesions. (b) Intracellular bacillus at the alveolar wall (arrow). (c) Intravascular bacillary clusters and embolus (arrow and inset) in a pulmonary arteriole (arrowheads showing the vascular endothelium/smooth muscle layer). (d) Intravascular, intracellular bacillus (arrow) in a pulmonary blood vessel. (e) Scattered individual bacilli (arrows) in the kidney glomerulus. (f) Small clusters of bacilli in the bone marrow. Liquid Permanent Red substrate with Mayer hematoxylin counterstain. Magnification: (a, e, and f): $\times 40$ objective; (c): $\times 20$ objective; (b and d and inset): $\times 100$ objective. Scale bars $=20 \mu \mathrm{m}$ (a, b, and d-f), $100 \mu \mathrm{m}$ (c); (a): case 3; (b-f): case 5 .

and found mainly in alveolar walls (Figure 1d) or spaces. Within blood vessels in the lung, liver, and heart, single bacillus or bacillary clusters were either 'free floating' or found within leukocytes (Figure 1e). No bacteria were detected in the stomach and kidney. 


\section{Discussion}

The in situ hybridization assay to detect B. pseudomallei is useful and sensitive enough to stain whole bacilli to facilitate localization and identification in infected tissues. As expected, in the human autopsy tissues, both intra- and extracellular bacteria were detected in the organs commonly reported to be involved, such as lung, spleen, liver, and kidney. ${ }^{19,20}$ In the lung and other organs, bacilli were detected in or around parenchymal inflammatory lesions, and occasionally also in alveolar walls and other tissues that were not obviously inflamed. Within some blood vessels, intracellular intact single bacillus (Figure 2d) and 'free-floating' extracellular single bacillus or small bacillary clusters could be unequivocally identified. Although it is well known that $B$. pseudomallei is able to survive and proliferate intracellularly, ${ }^{21}$ we believe this is the first time that bacteria have been demonstrated within circulating leukocytes in vivo. The overall morphological appearance of intact bacilli suggests that the bacteria were viable but further studies are needed to confirm this, and to identity which type of leukocyte could be infected intravascularly. It is possible that the intravascular, intracellular location could contribute to survival by helping bacteria evade the host immune response. Moreover, appropriate antibiotics may be less effective against intracellular bacteria. ${ }^{21}$ The rare, large bacillary cluster or embolus in B. pseudomallei septicemia bear some resemblance to the septic emboli described in hamsters experimentally infected with B. mallei. ${ }^{22}$ We speculate that bacillary emboli (Figure 2c) or smaller clusters may be held together and protected against antibiotics and host immune response by a surrounding biofilm, a well-known phenomenon in $B$. pseudomallei infection. ${ }^{23}$

Bone marrow infection, shown in one of our cases (case 5, Table 2), is consistent with bone marrow inflammation found in another series, ${ }^{24,25}$ and the observation that bacteria could be cultured from bone marrow. ${ }^{26}$ Morphologically intact bacteria were demonstrated in the wall of the mycotic aneurysm confirming $B$ pseudomallei infection (case 7, Table 2). Although generally mycotic aneurysm is rare in melioidosis, ${ }^{6}$ it has been reported that B. pseudomallei is the most common etiology of mycotic aneurysm in Thailand. ${ }^{7}$

The histology findings in the acute melioidosis mouse model appear to parallel the observations in the human tissues, although the mouse model was infected by the IP route whereas humans are usually infected via inhalation or skin inoculation. In particular, we were able to confirm intravascular, intracellular localization of bacteria in the mouse model (Figure 1e). Generally, bacilli stained more crisply, most likely because mouse tissues were formalin fixed immediately, whereas there is invariably some autolysis in human tissues because of autopsy delays. It may be possible to use in situ hybridization combined with other studies, for example ultrastruc- tural studies, to investigate whether intravascular, infected leukocytes may act as 'trojan horses' to penetrate vascular walls to cause parenchymal inflammation in the mouse model. As bacterial spread in lymphatics is unknown, ${ }^{27}$ our in situ hybridization technique could also be used to study this.

As the probes target 16s rRNA sequences, in addition to genomic DNA, theoretically it should be able to hybridize with the rRNA found in the thousands of free or membrane-bound ribosomes within a single bacteria cell. In practice, this strategy worked as single whole bacillus could be intensely and crisply stained. Our nonfluorescent colorimetric in situ hybridization assay has the advantage of allowing for direct visualization of bacilli and assessment of reactive changes in surrounding tissues. Our probe did not hybridize with the nonBurkholderia microorganisms and B. cepacia but cross-hybridized with $B$. thailandensis, although to a lesser extent. This is most likely because $B$. pseudomallei and B. thailandensis shared $>90 \%$ homology in the targeted rRNA region. Fortunately, $B$. thailandensis is an avirulent, nonpathogenic Burkholderia species ${ }^{28,29}$ and is an extremely rare infection in humans and animals, hence unlikely to be encountered in clinical materials/tissues. Higher stringency washes in the posthybridization step of the in situ hybridization procedure to minimize cross-hybridization were unsuccessful. A further drawback is that our in situ hybridization assay was not tested on $B$. mallei, although we predict our probe should cross-hybridize with $B$. mallei as the nucleotide homology in the targeted region is $100 \%$. Fortunately, like B. thailandensis, human B. mallei infection is rare compared with $B$. pseudomallei infections in endemic areas. Confirmation of B. pseudomallei infection in infected tissues can be done by performing a PCR on nucleic acid extracted from formalin-fixed, paraffin-embedded tissues. ${ }^{10}$ Using immunohistochemistry to detect B. pseudomallei is possible but it is very difficult to visualize individually stained bacteria, ${ }^{20}$ and there is often a high background of positively stained bacterial debris. The in situ hybridization assay is far better to visualize intact bacilli and there is relatively little background staining. We believe this is essential for diagnostic confidence.

We speculate that this method could be applied directly on smears for bacterial identification using bodily fluids or pus as was demonstrated for M. tuberculosis ${ }^{30}$ in sputum and Legionella spp. in bronchioalveolar lavages. ${ }^{31}$ Further tests and more extensive studies should be carried out to validate the usefulness of the probe for various clinical diagnostic purposes.

\section{Acknowledgments}

We thank Dr Yaiw Koon Chu for his kind guidance and advice in the development of the probe. The work 
was supported by the University of Malaya HIR Grant (H20001-E000004), PJP Grant (FS197/2008B), and PPP Grant (PV104/2011A), and the Stanford University-Malaysia Genome Institute-University of Malaya collaboration Grant (55-02-03-1044).

\section{Disclosure/conflict of interest}

The authors declare no conflict of interest.

\section{References}

1 Dance DA. Ecology of Burkholderia pseudomallei and the interactions between environmental Burkholderia spp. and human-animal hosts. Acta Trop 2000;74:159-168.

2 Chaowagul W, White NJ, Dance DA, et al. Melioidosis: a major cause of community-acquired septicemia in northeastern Thailand. J Infect Dis 1989;159:890-899.

3 Douglas MW, Lum G, Roy J, et al. Epidemiology of community-acquired and nosocomial bloodstream infections in tropical Australia: a 12-month prospective study. Trop Med Int Health 2004;9:795-804.

4 Puthucheary SD. Melioidosis in Malaysia. Med J Malaysia 2009;64:266-274.

5 Wuthiekanun V, Peacock SJ. Management of melioidosis. Expert Rev Anti Infect Ther 2006;4:445-455.

6 Currie BJ, Fisher DA, Howard DM, et al. Endemic melioidosis in tropical northern Australia: a 10-year prospective study and review of the literature. Clin Infect Dis 2000;31:981-986.

7 Siriluck A, Ploenchan C, Churairat K. Mycotic aneurysm in Northeast Thailand: the importance of Burkholderia pseudomallei as a causative pathogen. Clin Infect Dis 2008;47:1436-1439.

8 Ho CC, Lau CC, Martelli P, et al. A novel pan-genomic analysis approach in target selection for multiplex PCR identification and detection of Burkholderia pseudomallei, Burkholderia thailandensis and Burkholderia cepacia complex species: a proof-of-concept study. J Clin Microbiol 2011;49:814-821.

9 Meumann EM, Novak RT, Gal D, et al. Clinical evaluation of a type III secretion system real-time PCR assay for diagnosing melioidosis. J Clin Microbiol 2006;44:3028-3030.

10 Hagen RM, Gauthier YP, Sprague LD, et al. Strategies for PCR based detection of Burkholderia pseudomallei DNA in paraffin wax embedded tissues. Mol Pathol 2002;55:398-400.

11 Schmoocl G, Ehricht R, Melzer F, et al. DNA microarray-based detection and identification of Burkholderia mallei, Burkholderia pseudomallei and Burkholderia spp. Mol Cell Probes 2009;23:178-187.

12 Bashir DM. In situ hybridization for the identification of Helicobacter pylori in paraffin wax embedded tissue. J Clin Pathol 1994;47:862-864.

13 Hogardt M, Trebesius K, Geiger AM, et al. Specific and rapid detection by fluorescent in situ hybridization of bacteria in clinical samples obtained from cystic fibrosis patients. J Clin Microbiol 2000;38:818-825.

14 Palasubramaniam S, Muniandy S, Navaratnam P. Rapid detection of ESBL-producing Klebsilla pneumo- niae in blood cultures by fluorescent in-situ hybridization. J Microbiol Methods 2008;72:107-109.

15 Hagen RM, Frickmann H, Elschner M, et al. Rapid identification of Burkholderia pseudomallei and Burkholderia mallei by fluorescence in situ hybridization (FISH) from culture and paraffin-embedded tissue samples. Int J Med Microbiol 2011;301:585-590.

16 Kessler C, De Jong F. Digoxigenin DNA labelling and detection. Today Life Sci 1990;2:66-70.

17 Ong KC, Badmanathan M, Devi S, et al. Pathologic characterization of a murine model of human enterovirus 71 encephalomyelitis. J Neuropathol Exp Neurol 2008;67:532-542.

18 Brown RC, Hopps HC. Staining of bacteria in tissue sections; a reliable Gram stain method. Am J Clin Pathol 1973;60:234-240.

19 Wong KT, Puthucheary SD, Vadivelu J. The histopathology of human melioidosis. Histopathology 1995; 26:51-55.

20 Wong KT, Vadivelu J, Puthucheary SD, et al. An immunohistochemical method for the diagnosis of melioidosis. Pathology 1996;28:188-191.

21 Allwood EM, Devenish RJ, Prescott M, et al. Strategies for intracellular survival of Burkholderia pseudomallei. Front Microbiol 2011;2:170.

22 Fritz DL, Vogel P, Brown DR, et al. The Hamster model of intraperitoneal Burkholderia mallei (Glanders). Vet Pathol 1999;36:276-291.

23 Sawasdidoln C, Taweechaisupapong S, Sermswan RW, et al. Growing Burkholderia pseudomallei in biofilm stimulating conditions significantly induces antimicrobial resistance. PLoS One 2010;5:e9196.

24 Piggott JA, Hochholzer L. Human melioidosis. A histopathologic study of acute and chronic melioidosis. Arch Pathol 1970;90:101-111.

25 Greenawald KA, Nash G, Foley FD. Acute systemic melioidosis. Am J Clin Pathol 1969;52:188-198.

26 Dance DAB, White NJ, Suputtamongkol Y, et al. The use of bone marrow culture for the diagnosis of melioidosis. Trans R Soc Trop Med Hyg 1990;84: $585-587$.

27 Adler NRL, Govan B, Cullinane M, et al. The molecular and cellular basis of pathogenesis in melioidosis: how does Burkholderia pseudomallei cause disease? FEMS Microbiol Rev 2009;33:1079-1099.

28 Brett PJ, DeShazer D, Woods DE. Burkholderia thailandensis sp. nov., a Burkholderia pseudomallei-l i ke species. Int J Syst Bacteriol 1998;48:317-320.

29 Smith MD, Angus BJ, Wuthiekanun V, et al. Arabinose assimilation defines a nonvirulent biotype of Burkholderia pseudomallei. Infect Immun 1997;65: 4319-4321.

30 Stender H, Mollerup TA, Lund K, et al. Direct detection and identification of Mycobacterium tuberculosis in smear-positive sputum samples by fluorescence in situ hybridization (FISH) using peptide nucleic acid (PNA) probes. Int J Tubercul Lung Dis 1999;37:2760-2765.

31 Hayden RT, Uhl JR, Qian X, et al. Direct detection of Legionella species from bronchoalveolar lavage and open lung biopsy specimens: comparison of LightCycler PCR, in situ hybridization, direct fluorescence antigen detection, and culture. J Clin Microbiol 2001; 39:2618-2626. 